\title{
Assessment of Concentration, Erosivity and Seasonality of Precipitation Data for 1970-2019 Period of Karataş Gauging Station
}

\author{
Cihangir Koycegiz $^{1 *}$, Meral Buyukyildiz ${ }^{2}$ \\ $\mathbf{1}^{*}$ Konya Technical University, Faculty of Engineering and Natural Sciences, Departmant of Civil Engineering, Konya, Turkey, (ORCID: 0000-0002-0510-1164), \\ ckoycegiz@ktun.edu.tr \\ ${ }^{2}$ Konya Technical University, Faculty of Engineering and Natural Sciences, Departmant of Civil Engineering, Konya, Turkey, (ORCID: 0000-0003-1426-3314), \\ mbuyukyildiz@ktun.edu.tr
}

(International Conference on Design, Research and Development (RDCONF) 2021 - 15-18 December 2021)

(DOI: 10.31590 /ejosat.1040131)

ATIF/REFERENCE: Koycegiz, C. \& Buyukyildiz, M. (2021). Assessment of Concentration, Erosivity and Seasonality of Precipitation Data for 1970-2019 Period of Karataş Gauging Station. European Journal of Science and Technology, (32), 118-125.

\begin{abstract}
Temporal and spatial variations in precipitation as a result of the effects of climate change generally cause a flood, drought, soil erosion, etc. events to occur. For this reason, determining the precipitation variability in a region is quite important in protecting soil and water resources and in struggling soil erosion. This study aims to examine the monthly and annual variation of precipitation, annual and seasonal precipitation concentration (APCI and SPCI), annual and seasonal precipitation erosivity (AMFI) and SMFI, and seasonality of precipitation (SI) of the Karataş meteorological station in the Seyhan Basin for the period 1970-2019. In addition, the change of these parameters in the examined period was examined using the Mann-Kendall (MK) trend test. According to the results obtained, generally irregular and strong irregular precipitation distribution was obtained in the APCI values calculated for the Karataş station. According to SPCI analysis, $\mathrm{SPCI}_{\text {Winter }}$ values are uniform and moderate, $\mathrm{SPCI}_{\text {Spring }}$ values are moderate, $\mathrm{SPCI}$ Summer values are strongly irregular, and $\mathrm{SPCI}_{\text {Autumn }}$ values have moderate precipitation distribution. According to the AMFI values calculated to examine the precipitation erosivity, it was determined that the precipitation generally constitutes a high (34\%) and a quite high (40\%) erosion risk. According to seasonal MFI analysis results, $\mathrm{SMFI}_{\text {Winter }}$ values generally show a high and very high erosion risk, $\mathrm{SMFI}_{\text {Spring }}$ and $\mathrm{SMFI}_{\text {Summer }}$ values show no or very low erosion risk, and $\mathrm{SMFI}_{\text {Autumn }}$ values show moderate, high and very high (about $62 \%$ ) erosion risk. According to the SI analysis results of the 50-year study period, about half of the SI values represent significant seasonal precipitation with a long dry season. The Mann-Kendall trend results of monthly total precipitation, annual total precipitation, APCI, SPCI, AMFI, SMFI and SI values show that there are no significant trends for the 1970-2019 period.
\end{abstract}

Keywords: Erosivity, Mann-Kendall; Precipitation Concentration Index, Seasonality, Trend.

\section{Karataş Ölçüm İstasyonu 1970-2019 Periyodu Yağış Verilerinin Konsantrasyon, Erozivite ve Mevsimsellik Değerlendirilmesi}

Öz

İklim değişikliği etkilerinin bir sonucu olarak yağışlarda meydana gelecek zamansal ve mekansal değişkenlikler genellikle taşkın, kuraklık, toprak erozyonu vb olaylarının oluşmasına neden olmaktadır. Bu nedenle bir alan ya da bölgedeki yağı̧ değişkenliklerinin belirlenmesi toprak ve su kaynaklarının korunması, toprak erozyonu ile mücadelede oldukça önemlidir. Bu çalışma Seyhan Havzasında bulunan Karataş meteoroloji istasyonuna ait 1970-2019 periyodundaki yağış verilerinin aylık ve yıllık değişimini, yıllık ve mevsimlik yağış konsantrasyonunu (APCI ve SPCI), yıllık ve mevsimlik yağış erozivitesini (AMFI) ve SMFI) ve yağışın mevsimselliğini (SI) incelemeyi amaçlamaktadır. Ayrıca bu parametrelerin incelenen periyottaki değişimi Mann-Kendall (MK) trend testi kullanılarak incelenmiştir. Karataş istasyonu için hesaplanan APCI değerlerinde genellikle düzensiz ve güçlü düzensiz yağış dağılımı elde edilmiştir. SPCI analizlerine göre ise genellikle $\mathrm{SPCI}_{\mathrm{K}_{1 \S}}$ değerleri üniform ve orta düzey, $\mathrm{SPCI}_{\text {Ilkbahar }}$ değerleri orta düzey,

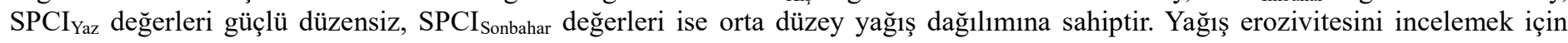

*Corresponding Author: ckoycegiz@ktun.edu.tr 
hesaplanan AMFI değerlerine göre ise yağışların genellikle yüksek (\%34) ve çok yüksek (\%40) erozyon riski oluşturduğu belirlenmiştir. Mevsimsel MFI analiz sonuçlarına göre ise genellikle $S M F I_{K ı s ̧ ~}$ değerleri yüksek ve çok yüksek erozyon riski, $\mathrm{SMFI}_{\text {Ilkbahar }}$ ve $\mathrm{SMFI}_{\text {Yaz }}$ değerleri erozyon riski yok veya çok düşük, SMFI $\mathrm{S}_{\text {Sonbahar }}$ değerleri ise orta, yüksek ve çok yüksek (yaklaşık \%62 oranında) erozyon riski göstermektedir. 50 yıllık çalışma periyoduna ait SI analiz sonuçlarına göre ise SI değerlerinin yaklaşık yarısı uzun bir kurak mevsim ile belirgin bir şekilde mevsimsel yağışları temsil etmektedir. Aylık toplam yağış, yıllık toplam yağış̧, APCI, SPCI, AMFI, SMFI ve SI değerlerinin Mann-Kendall trend sonuçları ise 1970-2019 periyodu için anlamlı trendler olmadığını göstermektedir.

Anahtar Kelimeler: Erozyon, Mann-Kendall, Yağış Konsantrasyon İndeksi, Mevsimsellik, Trend.

\section{Introduction}

Climate change and global warming cause changes in almost all components of the hydrological cycle. Precipitation is both one of the most important components of the hydrological cycle and one of the climate components where the effects of climate change are felt the most (Degefu \& Bewket, 2013). Precipitation is a climate component with a temporally and spatially variable and complex structure. Changes in the seasonality of precipitation can have significant effects on the magnitude and timing of erosive precipitation, which significantly affects water resource management, agricultural production, socio-economic activities and the ecosystem (Diodato \& Bellocchi, 2009; Back et.al., 2019; Zhang et al., 2021). One of the most important consequences of high precipitation events is flooding, but it can also cause soil erosion. Soil erosion can result in increases in the amount of sediment moving into rivers and the amount of pollutants reaching water supply systems. This can significantly affect water quality (Jebari et al., 2008; Munka et al., 2007). Therefore, understanding the variability of precipitation characteristics is important in assessing soil erosion and identifying areas exposed to this risk. It is thought that the findings to be obtained will be useful in determining the strategies to be applied for the protection and management of soil and water resources, especially in arid areas where important signs of such threats occur (Apaydin et al., 2006; Bayramin et al., 2006; De Luis et al., 2010; Guhathakurta \& Saji, 2013; Jebari et al., 2008; Huang et al., 2015). Many studies have been conducted in the literature on the temporal and spatial characteristics, seasonality, erosivity and concentration of precipitation (Guhathakurta \& Saji, 2013; Doyle, 2020; Zhang et al., 2021; Khalili et al., 2016; Nery et al., 2017; Nunes et al., 2016; Bayramin et al., 2006). Although it is known that precipitation varies greatly regionally and seasonally throughout Turkey, these features need to be represented by precipitation change indices. Such studies are important in terms of providing data for the approach and mathematical equations used for the assessment of flood and drought as well as soil erosion hazards.

This study aims to examine and evaluate i) temporal variation of monthly and annual precipitation data of Karataş meteorological station located in Seyhan Basin, ii) changes in seasonality, concentration and erosivity of precipitation. Nonparametric Precipitation Concentration Index, Modified Fournier
Index and Seasonality Index were used in these analyses. The trends of annual, monthly precipitation and related precipitation indices were examined by the Mann-Kendall test.

\section{Material and Method}

\subsection{Study Area}

In this study, precipitation data of Karataş station 17981 located in Seyhan Basin were used (Figure 1). This station has an altitude of $220 \mathrm{~m}$ and is located at $36^{\circ} 34^{\prime}$ north and $35^{\circ} 23^{\prime}$ east. Karataş station is in the downstream part of the Lower Seyhan Plain sub-basin and is located within the borders of Karataş district of Adana province. Karataş district is one of the regions where irrigation is the most intense and groundwater usage is the highest. Although the Mediterranean climate and terrestrial climate are observed in the Seyhan Basin, the region where Karataş station is located is under the influence of the Mediterranean climate. In this study, monthly and annual precipitation data for the period 1970-2019 measured at Karataş station were used. While $\mathrm{P}_{\text {mean }}=64.17 \mathrm{~mm}, \mathrm{P}_{\min }=0, \mathrm{P}_{\max }=513.6$ $\mathrm{mm}$ for monthly precipitation $(\mathrm{P})$ data, $\mathrm{P}_{\text {mean }}=770.05 \mathrm{~mm}$, $\mathrm{P}_{\min }=366.3, \mathrm{P}_{\max }=1269.6 \mathrm{~mm}$ for annual precipitation. The standard deviation and skewness values of the precipitation data are 80.82 (214.95) and 2.09 (0.33), respectively, monthly (or annually). The variation of monthly and annual precipitation over the period 1970-2019 is shown in Figure 2.

\subsection{Methodology}

\subsubsection{Precipitation Concentration Index}

The precipitation concentration index (PCI), developed by Oliver (1980) to examine the magnitude of precipitation concentration, expresses the degree of distribution of the annual total precipitation over 12 months. PCI is a strong indicator for the temporal distribution of precipitation (Zhang et al., 2019). Annual PCI (APCI) and seasonal PCI (SPCI) are calculated using Equations 1 and 2. In these equations, $P_{i}$ represents the monthly precipitation in $\mathrm{i}^{\text {th }}$. According to the obtained PCI values, the classification range is as follows. It is expressed as $\mathrm{PCI}<10$ (uniform precipitation distribution), $10 \leq \mathrm{PCI}<15$ (moderate precipitation distribution), $15 \leq \mathrm{PCI}<20$ (irregular precipitation distribution), $\mathrm{PCI} \geq 20$ (strong irregular precipitation distribution) (Zhang et al., 2019). 


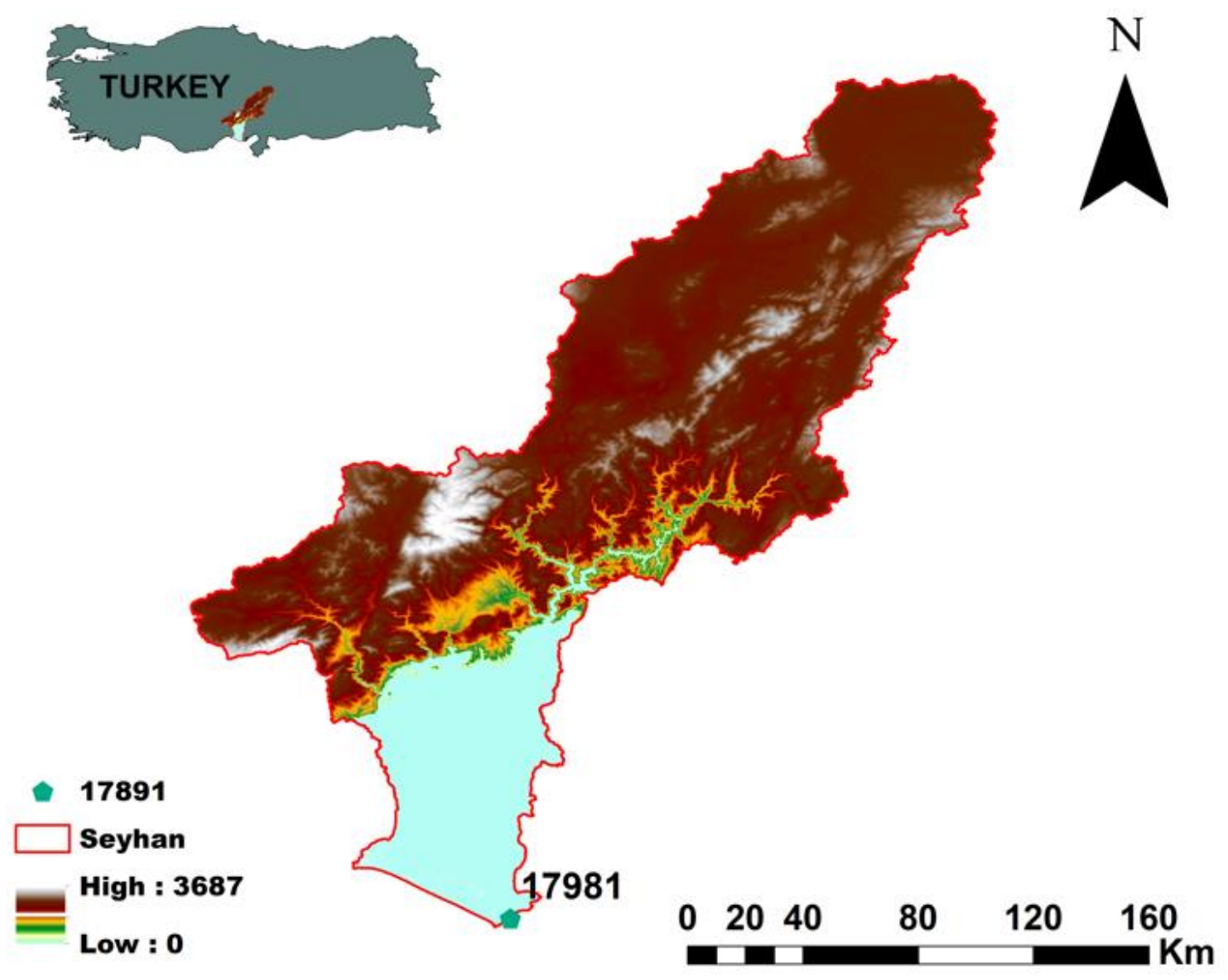

Figure 1. Location of Karataş meteorology station (No: 17981) in Seyhan Basin

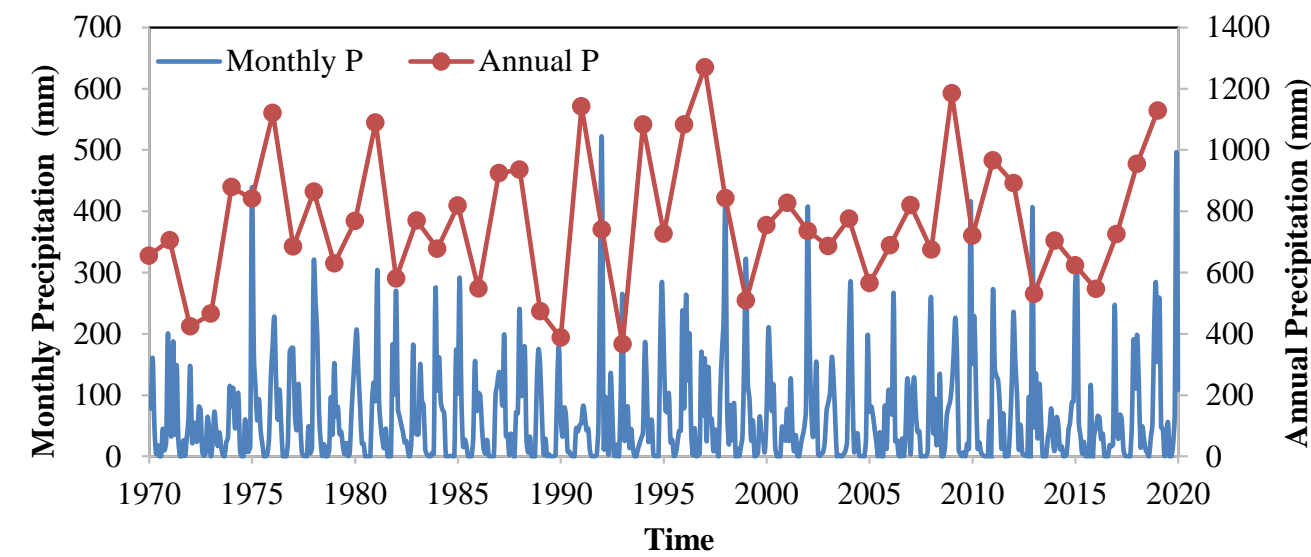

Figure 2. Karataş station monthly and annual precipitation change for the period 1970-2019

$A P C I=\frac{\sum_{i=1}^{12} P_{i}^{2}}{\left(\sum_{i=1}^{12} P_{i}\right)^{2}} \times 100$

$S P C I=\frac{\sum_{i=1}^{3} P_{i}^{2}}{\left(\sum_{i=1}^{3} P_{i}\right)^{2}} \times 25$

\subsubsection{Modified Fournier Index}

Modified Fournier Index (MFI), called precipitation erosivity index, was first proposed by Fournier (1960) and later developed by Arnoldus (1980). MFI is an index that deals with the relationship between transported material, climate data and topographic features. MFI is used as a guide in taking soil and water protection measures in areas with erosion risk, considering the erosive power of soils and precipitation characteristics. MFI is calculated on the annual scale (AMFI) and seasonal scale (SMFI) with Equations 3 and 4.

$$
\begin{aligned}
& A M F I=\frac{\sum_{i=1}^{12} P_{i}^{2}}{\sum_{i=1}^{12} P_{i}} \\
& S M F I=\frac{\sum_{i=1}^{3} P_{i}^{2}}{\sum_{i=1}^{3} P_{i}}
\end{aligned}
$$

By using this index, the erosion risk class values of precipitation are evaluated as significantly low if $\mathrm{MFI}<60$, low between 60-90, moderate between 90-120, high 120-160 and very high with $M F I \geq 160$ (Nunes et al., 2016). 


\subsubsection{Seasonality Index}

The Seasonality Index (SI) was developed by Walsh and Lawler (1981) and is an index that evaluates precipitation in terms of seasonality and also determines the degree of seasonal variation in precipitation. SI aims to characterize the distribution of precipitation throughout the year and to classify the climate of a region. The relative seasonality of precipitation shows the degree of variation in monthly precipitation throughout the year and considers seasonal variations in precipitation, rather than months being "dry" or "wet" in absolute terms (Walsh \& Lawler, 1981). Identifying changes in seasonal precipitation regime and
SI is essential for agricultural planning. The SI is a function of the monthly and annual total precipitation and is calculated mathematically by Equation 5 .

$$
S I_{i}=\frac{1}{R_{i}} \sum_{n=1}^{12}\left|X_{n i}-\frac{R_{i}}{12}\right|
$$

In this equation, $\mathrm{X}_{\mathrm{ni}}$ is the total precipitation for $\mathrm{n}$ months of year $i$ and $R_{i}$ is the total annual precipitation for year $i$. The classification of precipitation regimes according to the obtained SI values is given in Table 1.

Table 1. Seasonal precipitation regimes according to SI (Walsh \& Lawler, 1981)

\begin{tabular}{ll}
\hline Precipitation Regimes & SI \\
\hline Precipitation spread throughout by the year (very equable) & $\leq 0.19$ \\
Equable but with a definite wetter season & $0.20-0.39$ \\
Rather seasonal with a short drier season & $0.40-0.59$ \\
Seasonal & $0.60-0.79$ \\
Markedly seasonal with a long dry season & $0.80-0.99$ \\
Most precipitation in $<3$ months & $1.00-1.19$ \\
Extreme seasonality, with almost all precipitation in 1-2 months & $\geq 1.20$ \\
\hline
\end{tabular}

\subsubsection{Mann-Kendall Test}

The Mann-Kendall (Mann, 1945; Kendall, 1975) test is a non-parametric test, a special application of Kendall's Tau test, and is recommended by the World Meteorological Organization (WMO) (Mitchell, et al., 1966). In this method, the order of the data is based rather than the size, it can be used in the presence of missing data and the data doesn't have to comply with a certain distribution (Kahya \& Kalayci, 2004). Calculation steps and formulation of this method are not given here because they are available in many studies in the literature (Bhatti et al., 2020; Shawul \& Chakma, 2020). If the $\mathrm{z}$ value calculated as a result of the application of the method is positive, there is an increasing trend, and if it is negative, there is a decreasing trend. If the selected $\alpha$ significance level test statistic is $|z| \leq Z_{\text {critical }}$, the Ho hypothesis is accepted, otherwise it is rejected.

\section{Results and Discussion}

\subsection{Results of Annual and Seasonal Precipitation Concentration Index}

APCI and SPCI values were calculated using the monthly total precipitation data of Karatas station and their temporal changes are given in Figure 3 and Figure 4. According to Figure 3 , APCI values vary between 13.42 and 29.74 , and the average APCI $=19.57$ for the period of 1970-2019 examined. While there is no uniform precipitation distribution in any year in the precipitation data of Karataş station, generally irregular and strong irregular precipitation distribution has been obtained in the 50 years. There is moderate precipitation distribution in 10 years (20\%), irregular in 22 years (44\%), and strong irregular in 18 years (36\%). In the APCI values obtained, the average, irregular and strong irregular precipitation distribution values vary between 13.43-14.84, 15.22-19.78 and 20.58-29.74, respectively. The highest APCI value was 29.74 in 2015, and the lowest APCI value was 13.43 in 1972.

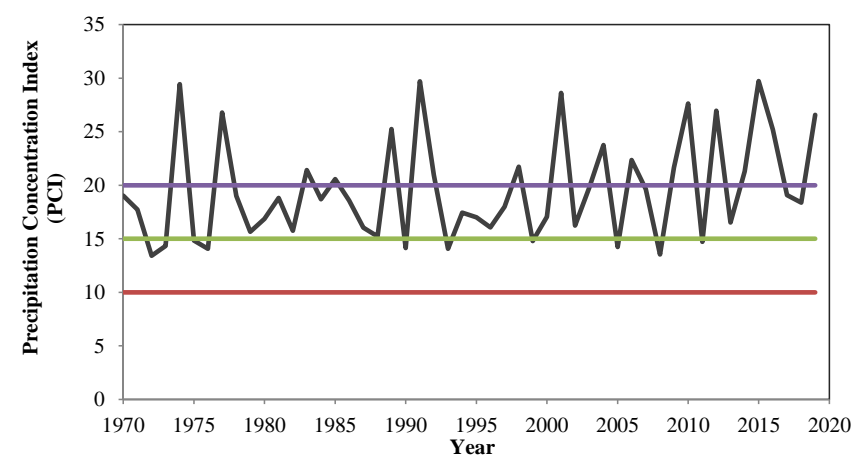

Figure 3. Temporal variation of PCI values on an annual scale

According to the graphs given in Figure 4, SPCI values generally show uniform and moderate precipitation variability in winter (December, January, February), and strong irregular precipitation distribution (>20) has not occurred in any year. In winter, there is an irregular distribution of precipitation in only three years (1972, 1993 and 1998). The year with the highest irregular precipitation was 1992 with SPCI=17.26 (Figure 4a). According to Figure $4 \mathrm{~b}$, precipitation variability in spring (March, April, May) is uniform (18\%) in nine years, irregular $(16 \%)$ in eight years, and strong irregular $(2 \%)$ in only one year. $64 \%$ of spring precipitation has moderate precipitation variability. The only year with strong irregular precipitation distribution was 2009 with SPCI=21.12. According to the SPCI graph (Figure 4c) in the summer season (June, July, August), there was no precipitation in years with $\mathrm{SPCI}=0$, while precipitation occurred in only one month in years with SPCI $=25$ (strong irregular) value. $60 \%$ of precipitation in this season is strongly irregular. The autumn (September, October, November) season generally has precipitation distributions similar to the spring season. According to SPCI values, precipitation generally has a moderate precipitation distribution (Figure 4d). From the temporal distribution graphs of the SPCI values in Figure 4, it is seen that smaller SPCI values are obtained in the winter, spring and autumn seasons with more precipitation and higher SPCI values are obtained in the summer seasons with less precipitation (Zhang et al., 2019). 


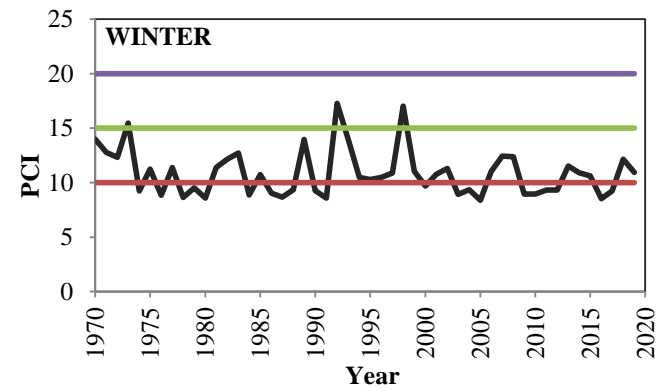

(a)

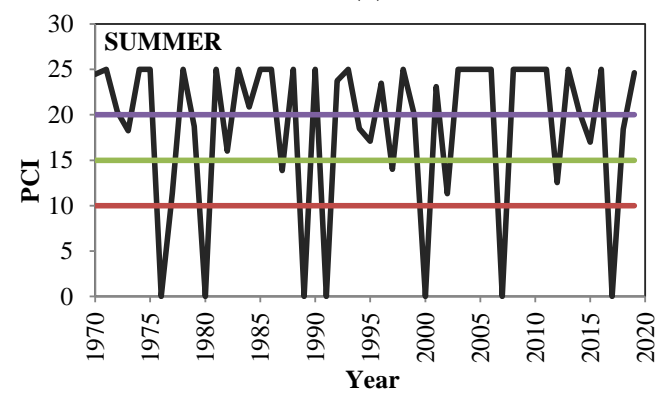

(c)

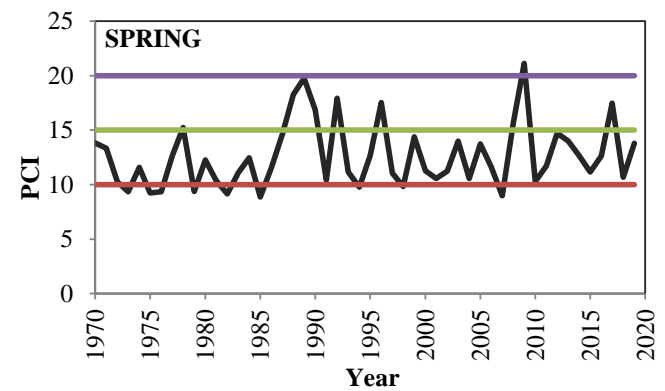

(b)

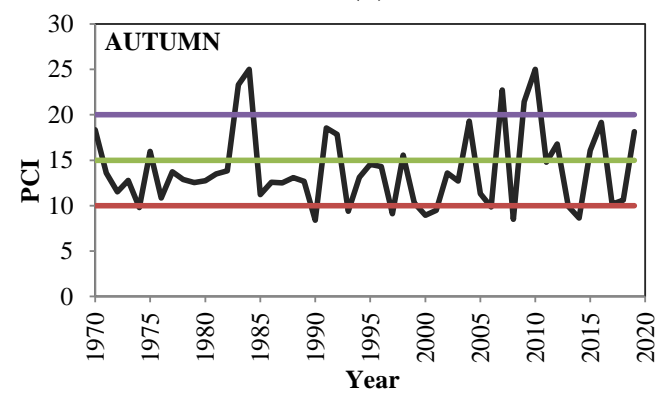

(d)

Figure 4. Temporal variation of PCI values on a seasonal scale: a) Winter, b) Spring, c) Summer, d) Autumn

\subsection{Results of Annual and Seasonal Modified Fournier Index}

The temporal variation of the annual MFI (AMFI) values obtained by using Karataş station precipitation data is given in Figure 5. The AMFI values obtained vary between 51.57 (1993) and 339.21 (1991), and the average AMFI value of Karataş station precipitation for the 1970-2019 period was 152.72 . According to AMFI values, $6 \%(\mathrm{MFI}<60)$ of the examined 50 year period does not occur precipitation at a level that can cause erosion, while precipitation creates a low risk of erosion in $8 \%$ $(60<\mathrm{MFI}<90)$. For the 50 years, the MFI ratios with moderate $(90<\mathrm{MFI}<120)$, high $(120<\mathrm{MFI}<160)$ and very high $(>160)$ erosion risk were found to be $12 \%, 34 \%$, and $40 \%$, respectively. Especially with the value of $\mathrm{MFI}=339.21,1991$ was the year in which the precipitation, which created a very high risk of erosion, was seen.

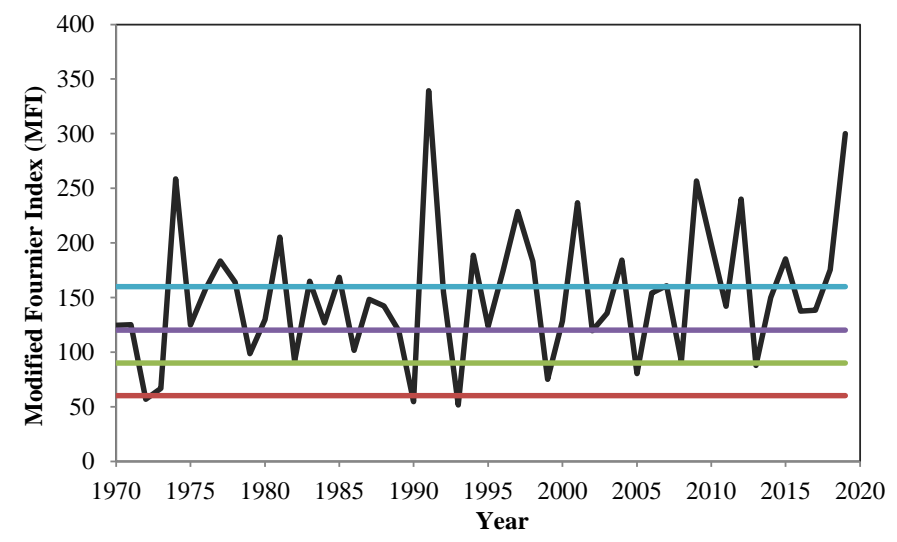

Figure 5. Temporal variation of MFI values on an annual scale
For Karataş station, MFI, which is an indicator of precipitation erosivity and precipitation intensity, is calculated seasonally and its temporal changes are given in Figure 6. The SMFI values obtained for the winter season vary between 53.94 and 434.64, with an average of 165.36 for the period 1970-2019. The highest SMFI value for the winter season was obtained in 1992, as in the PCI values obtained for the same season. SMFI values were found to be very high $(50 \%)$ and high $(20 \%)$ erosion risk in winter (Figure $6 a$ ). While a moderate erosion risk of $14 \%$ and a low erosion risk of $10 \%$ were obtained, MFI values that do not pose an erosion risk were obtained in only 3 years $(6 \%)$. It is seen from Figure $6 \mathrm{~b}$ that the SMFI values obtained for the spring are lower than the winter. SMFI values vary between 14.57 and 171.11 during this season. With a rate of $52 \%(\mathrm{MFI}<60)$, most of the precipitation does not have the risk of erosion. There is also a low risk of erosion in $22 \%(60<\mathrm{MFI}<90)$. MFI values are between 90 and 120 at 9 years and between 120 and 160 at 3 years. According to Figure 6b, precipitation that poses a very high erosion risk in the spring season was obtained only in 1996 (SMFI=171.11). For summer, SMFI values ranged from 0 to 73.5 (Figure $6 \mathrm{c}$ ). It can be seen from Figure $6 \mathrm{c}$ that, according to the SMFI values obtained in the summer season, precipitation in only four years creates a low erosion risk, while precipitation in other years does not create an erosion risk. The change in the SMFI values obtained for the autumn is shown in Figure 6d. SMFI values vary between 13.06 and 427.91 in this season. The average of the SMFI values for the autumn season in the examined period is 132.04 . For the autumn season, in the 50year period, $30 \%$ of the SMFI values are very high, $14 \%$ are high, $18 \%$ are moderate, $14 \%$ are low erosion risks, while $24 \%$ do not create a significant erosion risk. 


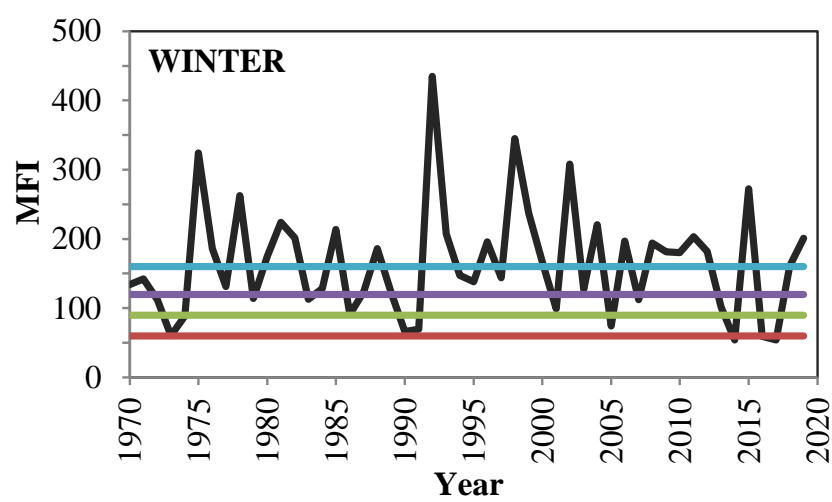

(a)

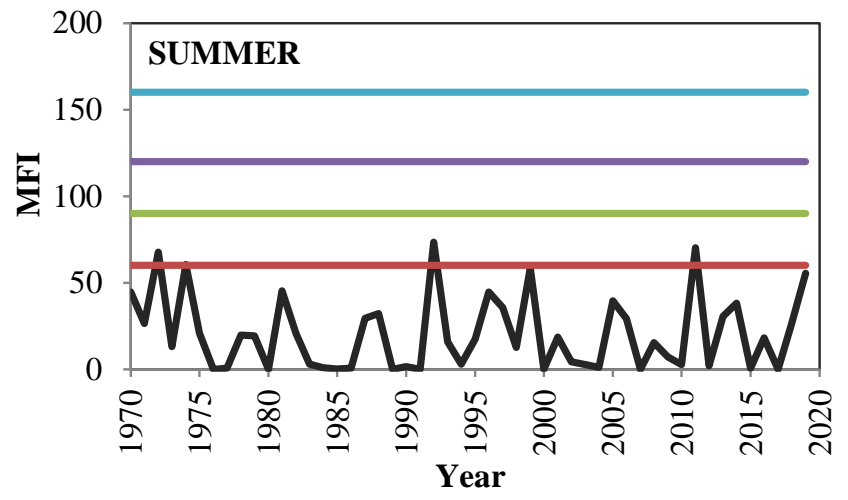

(c)

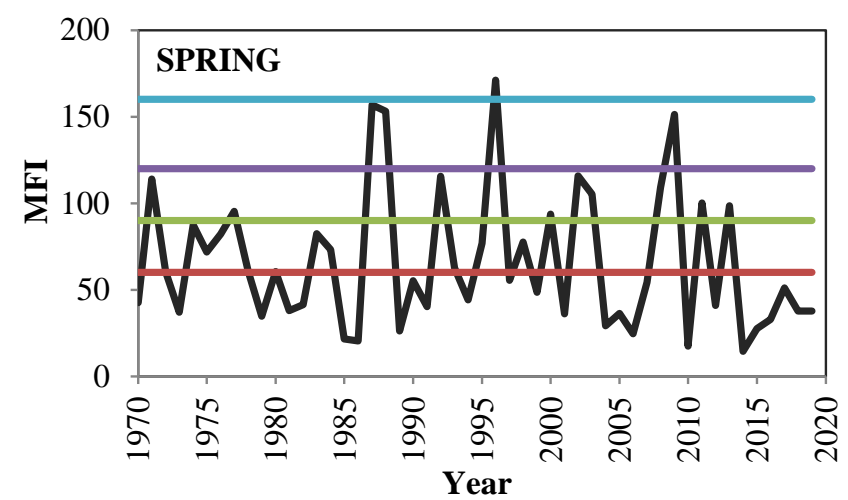

(b)

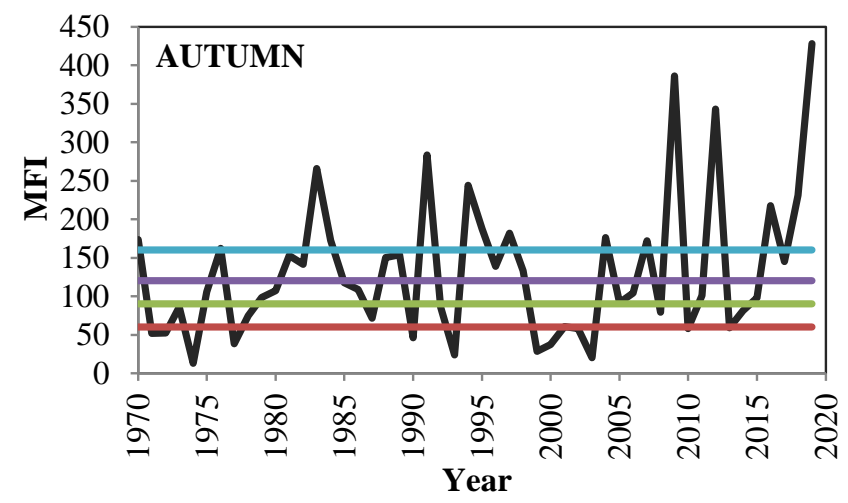

(d)

Figure 6. Temporal variation of MFI values on a seasonal scale: a) Winter, b) Spring, c) Summer, d) Autumn

\subsection{Results of Seasonality Index}

To evaluate the precipitation of Karataş Station in terms of seasonality, the Seasonality Index (SI) was applied to the monthly total precipitation in the 1970-2019 periods and the temporal variation of the obtained values is given in Figure 7.

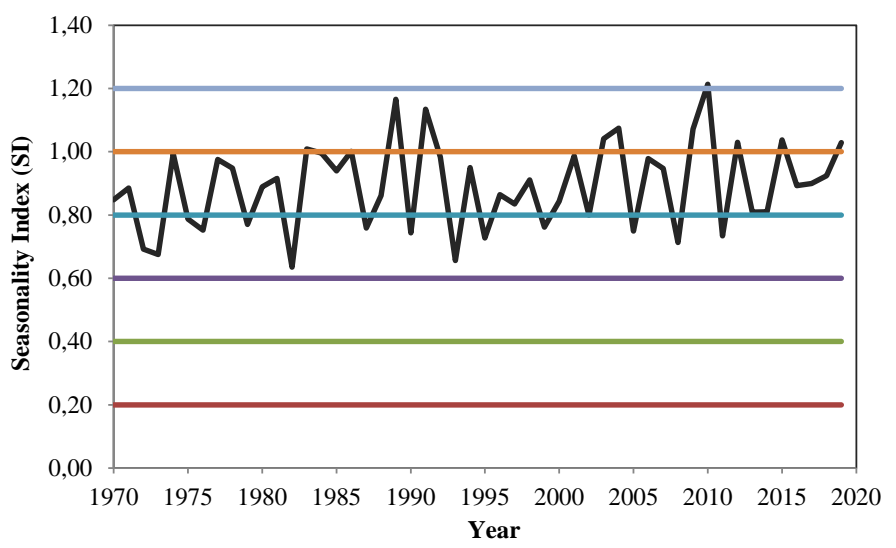

Figure 7. Temporal variation of SI values on an annual scale

The SI values obtained vary between 0.64 and 1.21 , with the average $\mathrm{SI}=0.89$ for the 50 -year period. None of the SI values are among the first three classes indicated in Table 1. It can be seen from Figure 7 that the maximum SI value $(>1.20)$ was achieved only in 2010. There are heavy rains in one or two months of this year and the precipitations show extreme seasonality. SI values between 1 and 1.19 were achieved at only 11 years $(22 \%)$ over a 50 -year study period. This shows that according to Table 1 , most of the precipitation in the relevant years took place in less than three months. In Figure 7, it can be seen that most of the SI values (46\%) ranged between 0.8 and 0.99 , which represents significant seasonal precipitation with a long dry season according to the classification in Table $1.32 \%$ of the SI values are between 0.6 and $0.79 \%$, which is characterized as the seasonal regime (Table 1) in precipitation and less precipitation is seen in winter months.

\subsection{Results of Mann-Kendall Trend}

Mann-Kendall (MK) trend test was applied in order to examine the variation of the calculated APCI, SPCI, MFI, SMFI and SI data with the monthly and annual total precipitation data of the Karataş meteorological station in the Seyhan Basin for the study period (1970-2019). The results are given in Table 2. Obtained results were evaluated according to $\alpha=0.05$ significance level. Since the $\mathrm{z}$ values of the MK test statistic given in Table 2 are less than the $z_{\text {critical }}=1.96$ value, which corresponds to $\alpha=0.05$ significance level, as an absolute value, there is no statistically significant trend in any of the examined parameters. The fact that all $\mathrm{p}$ values in Table 2 are above 0.05 indicates that there is no significant trend. However, the negative $\mathrm{S}$ and $\mathrm{z}$ values are given in Table 2 for monthly precipitation, $\mathrm{PCI}_{\text {winter, }}$ MFI $\mathrm{I}_{\text {Spring, }} \mathrm{MFI}_{\text {Summer }}$ indicate an insignificant decreasing trend for these time series, and positive $\mathrm{S}$ and $\mathrm{z}$ values for other parameters indicate an insignificant increase trend. 
Table 2. Mann-Kendall trend analysis results

\begin{tabular}{cccccc}
\hline Season & & $\mathrm{S}$ & $\mathrm{Z}$ & $\mathrm{p}$ value & Trend \\
\hline Monthly & Precipitation & -1454 & -0.30 & 0.7671 & $\mathrm{INT}$ \\
\hline Annual & Precipitation & 67 & 0.55 & 0.5809 & IPT \\
\hline Annual & PCI & 233 & 1.94 & 0.0523 & IPT \\
\hline \multirow{3}{*}{ Seasonal } & Winter PCI & -109 & -0.90 & 0.3663 & INT \\
\cline { 2 - 5 } & Spring PCI & 186 & 1.55 & 0.1217 & IPT \\
\cline { 2 - 5 } & Summer PCI & 11 & 0.08 & 0.9333 & IPT \\
\cline { 2 - 5 } & Autumn PCI & 12 & 0.09 & 0.9267 & IPT \\
\hline Annual & MFI & 205 & 1.71 & 0.0879 & IPT \\
\hline \multirow{3}{*}{ Seasonal } & Winter MFI & 3 & 0.02 & 0.9867 & IPT \\
\cline { 2 - 5 } & Spring MFI & -145 & -1.21 & 0.2284 & INT \\
\cline { 2 - 5 } & Summer MFI & -34 & -0.28 & 0.7825 & INT \\
\cline { 2 - 5 } & Autumn MFI & 169 & 1.41 & 0.1599 & IPT \\
\hline Annual & SI & 177 & 1.47 & 0.1410 & IPT \\
\hline & IPT: Insignificant positive trend & & \\
& INT: Insignificant negative trend & &
\end{tabular}

\section{Conclusions and Recommendations}

It is very important to examine the temporal/spatial variability, seasonality, concentration and erosivity of historical precipitation data in order to combat flood and drought events that may occur as a result of hydrological studies, water resources management, agricultural production, socio-economic activities, and the effects of climate change. At the same time, examining precipitation variability in a given region is critical to reliably conducting future climate projection studies. In this study, annual PCI (APCI) and seasonal PCI (SPCI), annual MFI (AMFI) and seasonal MFI (SMFI) and annual SI values were obtained by using the monthly total precipitation data of the Karataş meteorological station in the Seyhan Basin for the period 1970-2019. According to the results obtained in these indexes, most of the APCI values calculated for Karataş station represent irregular and strong irregular precipitation distribution. According to the SPCI results, in general, a uniform and moderate precipitation distribution was obtained in $\mathrm{SPCI}_{\text {Winter, }}$ moderate precipitation in $\mathrm{SPCI}_{\text {spring, strongly irregular in }}$ $\mathrm{SPCI}_{\text {Summer, }}$ and moderate precipitation in $\mathrm{SPCI}_{\text {Autumn. }}$. According to the AMFI values calculated to examine the erosivity of Karataş precipitation, it has been determined that precipitations in the 50-year period generally pose a high (34\%) and a very high $(40 \%)$ erosion risk. According to the SMFI analysis results, $\mathrm{SMFI}_{\text {Winter }}$ is generally high and has a very high erosion risk, $\mathrm{SMFI}_{\text {Spring }}$ and $\mathrm{SPCI}_{\text {Summer }}$ have no or very low erosion risk, and $\mathrm{SMFI}_{\text {Autumn }}$ has moderate, high and very high (about 62\%) erosion risk precipitation. Approximately half of the values obtained in the SI analysis results of the 50-year study period represent seasonal precipitation with a long dry season. In the index values of precipitation concentration, erosivity and seasonality, and the Mann-Kendall trend results applied to the monthly total precipitation and annual total precipitation values, no significant trends were found for the study period according to the 0.05 significance level. However, insignificant negative trends were found for monthly total precipitation, SPCI ${ }_{\text {Winter, }}$

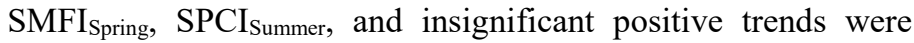
found for other parameters.

\section{References}

Apaydin, H., Erpul, G., Bayramin, I., \& Gabriels, D. (2006). Evaluation of indices for characterizing the distribution and concentration of precipitation: a case for the region of Southeastern Anatolia Project, Turkey. Journal of Hydrology, 328, 726-732.

Arnoldus, H. M. J. (1980). An approximation of the rainfall factor in the Universal Soil Loss Equation. In: De Boodt M, Gabriels D (eds), Assessment of Erosion, John Wiley \& Sons, New York.

Back, Á. J., Gonçalves, F. N., \& Fan, F. M. (2019). Spatial, seasonal, and temporal variations in rainfall aggressiveness in the south of Brazil. Eng. Agrícola, 39, 466-475.

Bayramin, I., Erpul, G., \& Erdogan, H. E. (2006). Use of CORINE methodology to assess soil erosion risk in the semi-arid area of Beypazar1, Ankara. Turk. J. Agric. For., 30, 81-100.

Bhatti, A. S., Wang, G., Ullah, W., Ullah, S., Tawia Hagan, D. F., Nooni, I. K., Lou, D., \& Ullah, I. (2020). Trend in extreme precipitation indices based on long term In situ precipitation records over Pakistan. Water, 12, 1-19.

De Luis, M., Gonzales-Hidalgo, J.C., \& Longares, L. A. (2010). Is rainfall erosivity increasing in the Mediterranean Iberian Peninsula?. Land Degrad. Dev., 21, 139-144.

Degefu, M. A., \& Bewket, W. (2013). Variability and trends in rainfall amount and extreme event indices in the Omo-Ghibe River Basin, Ethiopia. Reg Environ Change, 14, 799-810.

Diodato, N., \& Bellocchi, G. (2009). Assessing and modelling changes in rainfall erosivity at different climate scales. Earth Surface Processes and Landforms, 34(7), 969-980.

Doyle, M. E. (2020). Observed and simulated changes in precipitation seasonality in Argentina. Int $J$ Climatol. , 40, 1716-1737.

Fournier, F. (1960). Climat et erosion: la relation entre l'érosion du sol par l'eau et les précipitations atmosphériques. Paris: Presses Universitaires de France. 
Guhathakurta, P., \& Saji, E. (2013). Detecting changes in rainfall pattern and seasonality index vis-a-vis increasing water scarcity in Maharashtra. J. Earth Syst. Sci., 122(3), 639-649.

Huang, J., Liu, F., Xue, Y., \& Sun, S. (2015). The spatial and temporal analysis of precipitation concentration and dry spell in Qinghai, northwest China. Stoch Environ Res Risk Assess, 29, 1403-1411.

Jebari, S., Berndtsson, R., Bahri, A., \& Boufaroua, M. (2008). Exceptional Rainfall Characteristics Related to Erosion Risk in Semiarid Tunisia. The Open Hydrology Journal, 1, 25-33.

Kahya, E., \& Kalayci, S. (2004). Trend analysis of streamflow in Turkey. Journal of Hydrology, 89, 128-144.

Kendall, M. G. (1975). Rank Correlation Methods. London: Griffin.

Khalili, K., Tahoudi, M. N., Mirabbasi, R., \& Ahmadi, F. (2016). Investigation of spatial and temporal variability of precipitation in Iran over the last half century. Stoch Environ Res Risk Assess, 30, 1205-1211.

Mann, H. B. (1945). Nonparametric tests against trend. Econometrica, 13, 245-259.

Mitchell, J. M., Dzerdzeevskii, B., Flohn, H., Hofmeyr, W. L., Lamb, H.C., Rao, K N., et al. (1966). Climate change (Cilt No.79). Geneva: WMO Technical Note.

Munka, C., Cruz, G., \& Caffera, R. M. (2007). Long term variation in rainfall erosivity in Uruguay: a preliminary Fournier approach. GeoJournal, 70, 257-262.

Nery, J. T., Carfan, A. C., \& Martin-Vide, J. (2017). Analysis of Rain Variability Using the Daily and Monthly Concentration
Indexes in Southeastern Brazil. Atmospheric and Climate Sciences, 7, 176-190.

Nunes, A. N., Lourenço, L., Vieira, A., \& Bento-Gonçalve, A. (2016). Precipitation and erosivity in Southern Portugal: seasonal variability and trends (1950-2008). Land Degrad. Dev, 27, 211-222.

Oliver, J. E. (1980). Monthly precipitation distribution: a comparative index. Prof Geogr, 32, 300-309.

Shawul, A. A., \& Chakma, S. (2020). Trend of extreme precipitation indices and analysis of long-term climate variability in the Upper Awash Basin, Ethiopia. Theoretical and Applied Climatology, 140, 635-652.

Walsh, R. P. D., \& Lawler, D. M. (1981). Rainfall seasonality: Description, spatial patterns and change through time. Weather, 36(7), 201-208.

Zhang, D., Wang, T., Liu, Y., Zhang, S., \& Meng, X. (2021). Spatial and temporal characteristics of annual and seasonal precipitation variation in Shijiazhuang region, north China. Environ Earth Sci, 80, 656.

Zhang, K., Yao, Y., Qian, X., \& Wang, J. (2019). Various characteristics of precipitation concentration index and its cause analysis in China between 1960 and 2016. Int $J$ Climatol, 1-11. 